\title{
Pemutusan Hubungan Kerja Terhadap Pekerja/Buruh Perempuan Harian Lepas oleh Perusahaan Karena Alasan Cuti Haid
}

\author{
Ferdy Dwiyanda Putra \\ ferdydwip@gmail.com \\ Universitas Airlangga
}

Keywords:
Female Workers /
Laborers; Casual
Daily; Work
Agreement For
A Certain Time;
Termination Of
Employment;
Menstruation
Leave.

Keywords:

Abstract

Termination of work relations by companies to casual daily female workers / workers for reasons of menstrual leave is still prevalent to this day, where companies in providing menstrual leave rights to female workers / laborers are still not in accordance with applicable laws and regulations. This is because companies are often reluctant to give away these rights on the grounds that they fear that the rights will be abused by female workers in the company. On the other hand, many female workers / laborers do not yet know that there are leave rights for female workers / laborers who experience pain during menstruation so that when there is a termination of employment by the company against women workers / laborers who do not come to work for menstrual reasons, workers / the female laborer can only accept it gracefully. In fact, if referring to the provisions of Article 81 of Law Number 13 Year 2003 concerning Labor, the right of leave during menstruation can be given to female workers / laborers as long as they are regulated in a work agreement, company regulations, or collective labor agreement. If it is stipulated in a work agreement, company regulations, or collective labor agreement, but the company continues to terminate employment for this reason, then female workers can seek compensation to their company or can be resolved through legal or non-legal channels.

Kata Kunci:
Pekerja/Buruh
Perempuan;
Harian Lepas;
Perjanjian Kerja
Waktu Tertentu;
Pemutusan
Hubungan Kerja;
Cuti Haid.

\section{Abstrak}

Pemutusan hubungan kerja oleh perusahaan terhadap pekerja/buruh perempuan harian lepas karena alasan cuti haid masih banyak terjadi hingga saat ini, dimana perusahaan dalam memberikan hak cuti haid kepada pekerja/buruh perempuan tersebut masih belum sesuai dengan peraturan perundang-undangan yang berlaku. Hal ini dikarenakan pihak perusahaan seringkali enggan memberikan hak tersebut dengan alasan takut hak tersebut disalahgunakan oleh pekerja/buruh perempuan diperusahaannya. Disisi lain, pekerja/buruh perempuan banyak yang belum mengetahui bahwa terdapat hak cuti kepada pekerja/buruh perempuan yang mengalami rasa sakit pada masa haid sehingga ketika terjadi pemutusan hubungan kerja oleh perusahaan terhadap pekerja/buruh perempuan yang tidak masuk kerja karena alasan haid, pekerja/buruh perempuan tersebut hanya dapat menerimanya dengan lapang dada. Padahal, apabila merujuk ketentuan Pasal 81 Undang-Undang Nomor 13 Tahun 2003 tentang Ketenagakerjaan hak cuti pada masa haid tersebut dapat diberikan kepada pekerja/buruh perempuan sepanjang diatur dalam perjanjian kerja, peraturan perusahaan, atau perjanjian kerja bersama. Apabila telah diatur dalam perjanjian kerja, peraturan perusahaan, atau perjanjian kerja bersama, namun perusahaan tetap melakukan pemutusan hubungan kerja dengan alasan tersebut, maka pekerja/buruh perempuan dapat mengupayakan ganti kerugian kepada perusahaannya atau dapat diselesaikan dengan jalur hukum maupun non hukum. 


\section{Pendahuluan}

Pada masa ini, tidak sedikit perempuan berperan aktif dalam kesejahteraan keluarga dengan cara bekerja merupakan hal yang sudah biasa karena perempuan memiliki potensi juga yang tidak kalah dibandingkan dengan kaum laki-laki, baik dari segi intelektual, kemampuan, maupun keterampilan. Apalagi dengan semakin meningkatnya perkembangan di dunia industrial dan teknologi membawa perempuan pada posisi yang sejajar dengan laki-laki. Meskipun demikian, pekerja atau buruh perempuan juga manusia yang mempunyai kebutuhan sosial, sehingga memerlukan kebutuhan pokok, kesehatan, perumahan, ketentraman, dan sebagainya untuk pekerja/buruh dan keluarga pekerja/buruh tersebut. Mengingat pekerja/buruh adalah pihak yang lemah dari pengusaha yang kedudukannya lebih kuat. Maka pekerja/buruh perlu mendapatkan perlindungan atas hak-haknya. ${ }^{1}$

Secara teori, terdapat 3 (tiga) bentuk perlindungan tenaga kerja yang dikenal, yaitu sebagai berikut: ${ }^{2}$

1. Perlindungan yang dilihat dari segi ekonomis, yakni suatu bentuk perlindungan tenaga kerja yang diberikan kepada para pekerja/buruh berupa suatu imbalan atau penghasilan yang cukup untuk memenuhi kebutuhan sehari-hari. Selain itu, perlindungan ini juga mengatur dalam hal pekerja/ buruh tersebut tidak sanggup melakukan pekerjaannya karena sesuatu hal di luar yang dikehendaki pekerja/buruh tersebut. Perlindungan bentuk ini biasanya disebut sebagai jaminan sosial;

2. Perlindungan yang dilihat dari segi teknis, yaitu suatu jenis perlindungan yang diberikan kepada pekerja/buruh yang bertujuan agar pekerja/buruh yang melakukan sebuah pekerjaan merasakan rasa aman dari segala bahaya yang dapat timbul dari alat-alat kerja atau bahan yang dikerjakan. Perlindungan bentuk ini biasanya disebut sebagai keselamatan kerja;

\footnotetext{
${ }^{1}$ Ni Wayan Mega Jayantri, 'Perlindungan Hukum Terhadap Pekerja Perempuan Pada Malam Hari Di Minimarket Alfamart Mataram (Studi Berdasarkan Undang-Undang No. 13 Tahun 2003 Tentang Ketenagakerjaan)' (2013) 1 Jurnal Ilmiah.[4].

${ }^{2}$ Zaeni Asyhadie, Hukum Kerja: Hukum Ketenagakerjaan Bidang Hubungan Kerja (Rajawali Pers 2013).[84]
} 
3. Perlindungan yang dilihat dari segi sosial, yaitu suatu bentuk perlindungan yang diberikan kepada pekerja/buruh yang bertujuan memberikan hak mengenai kesehatan dalam kehidupannya. Perlindungan ini dapat disebut sebagai kesehatan kerja.

Pada prakteknya, objek perlindungan tenaga kerja yang diatur dalam Undang-Undang Nomor 13 Tahun 2003 tentang Ketenagakerjaan (selanjutnya disebut UU Ketenagakerjaan) menyebutkan bahwa pada pekerja/buruh perempuan memiliki perlindungan yang khusus karena kondisi biologis yang berbeda dengan pekerja/buruh laki-laki. Perlindungan hukum kepada pekerja/ buruh perempuan tersebut merupakan suatu pemenuhan hak dasar yang melekat dan dilindungi oleh Konstitusi sebagaimana yang telah diatur dalam Pasal 27 ayat (2) Undang-Undang Dasar Negara Republik Indonesia Tahun 1945 (selanjutnya disebut UUD NRI Tahun 1945).

Salah satu perlindungan hukum yang dikhususkan untuk pekerja/ buruh perempuan adalah perlindungan yang bersifat protektif. Dengan fungsi reproduksi perempuan, perempuan memiliki masa haid di setiap bulannya. Kebanyakan perempuan merasakan rasa sakit saat haid tersebut di hari pertama dan hari kedua masa haid. Sehingga oleh UU Ketenagakerjaan memberikan hak kepada pekerja/buruh perempuan untuk libur bekerja di hari pertama dan hari kedua saat merasakan sakit masa haid sebagaimana ketentuan Pasal 81 ayat (1).

Di Indonesia sendiri, terdapat 2 bentuk perjanjian kerja yang diatur di dalam peraturan perundang-undangan, yaitu Perjanjian Kerja Waktu Tertentu (yang selanjutnya disebut dengan PKWT) yang biasa disebut sebagai pekerja kontrak, dan Perjanjian Kerja Waktu Tidak Tentu (yang selanjutnya disebut PKWTT) yang biasa disebut sebagai pekerja tetap. Ketentuan yang mengatur mengenai PKWT ada di dalam Pasal 56 ayat (2) UU Ketenagakerjaan menyebutkan bahwa “perjanjian kerja untuk waktu tertentu (PKWT) didasarkan atas jangka waktu atau selesainya satu pekerjaan tertentu." PKWT hanya dapat dibuat untuk pekerjaan tertentu yang menurut jenis dan sifat atau kegiatan pekerjaannya akan selesai 
dalam waktu tertentu, yaitu: ${ }^{3}$

1. Pekerjaan yang memiliki sifat musiman, yaitu pekerjaan yang hanya dapat dilakukan dalam musim tertentu berdasarkan musim atau cuaca;

2. Pekerjaan yang memiliki sifat sementara yaitu pekerjaan yang hanya satu kali selesai pekerjaan;

3. Pekerjaan yang diselesaikan dengan jangka waktu yang singkat dan tidak lebih dari 3 (tiga) tahun penyelesaian suatu pekerjaan; atau

4. Pekerjaan yang diberikan hanya pada saat terdapat produk baru atau kegiatan baru yang masih dalam masa percobaan.

Dalam prakteknya, kebanyakan pengusaha memilih untuk menerapkan sistem PKWT. Bagi para pengusaha atau pemberi kerja, PKWT dianggap lebih menguntungkan dibandingkan dengan menerapkan sistem perjanjian kerja waktu tidak tertentu. Namun secara normatif, sistem yang dilakukan oleh perusahaan tersebut seringkali merugikan pekerja. Pekerja akan merasa tidak tenang dikarenakan sifat sementara dari kesepakatan kerja yang diterimanya. Terdapat tidak sedikit juga perusahaan yang diduga mengambil keuntungan dari sistem PKWT ini tanpa memperhatikan pekerja/buruhnya bahkan banyak pula perusahaan yang tidak memperhatikan ketentuan-ketentuan dalam UU Ketenagakerjaan. Sehubungan dengan hal tersebut, mengakibatkan sering terjadinya perselisihan antara pekerja/ buruh dengan perusahan yang sulit dihindarkan.

Salah satu perselisihan tersebut yaitu soal pemutusan hubungan kerja. Pemutusan hubungan kerja terhadap pekerja/buruh perempuan akan menjadikan pekerja/buruh perempuan tersebut kehilangan mata pencaharian, yang berarti pula permulaan masa pengangguran dengan segala akibatnya. Hal ini juga berarti merupakan tidak mencukupinya kebutuhan hidup dirinya dan keluarganya supaya tetap bertahan hidup.

Pemutusan Hubungan Kerja (PHK) yang sering terjadi adalah PHK yang dilakukan oleh pihak pengusaha yang disebabkan pekerja perempuan berhalangan menjalankan pekerjaan atau melanggar perjanjian kerja karena masa haid yang semuanya adalah hak yang kodrati dari perempuan yang dalam hal ini merugikan

3 Hardijan Rusli, Hukum Ketenagakerjaan (Ghalia Indonesia 2004). [66]. 
pihak perusahaan dan pihak perusahaan tidak memberikan cuti pada pekerja, padahal pemberian cuti itu sudah menjadi kewajibannya selain memberi upah.

Maka menurut ketentuan yang ada seharusnya tenaga kerja perempuan yang terikat pada perjanjian kerja waktu tertentu (PKWT) atau harian lepas maupun dalam ikatan perjanjian kerja waktu tidak tertentu (PKWTT) diberikan masa cuti saat hari pertama dan hari kedua masa haid yang telah diatur dalam UU Ketenagakerjaan. Akan tetapi praktiknya, masih banyak perusahaan yang tidak memberikan cuti haid kepada para pekerja/buruh perempuan. sehingga seringkali terjadi dalam praktek banyak pekerja/buruh perempuan harian lepas yang diberikan pemutusan hubungan kerja oleh perusahaan.

Hal tersebut sama terjadi di dalam kasus PT. PEI HAI di Kabupaten Jombang yang diberitakan di salah satu surat kabar jombang yang mana berita tersebut memberitakan telah terjadi pemutusan hubungan kerja oleh PT. PEI HAI terhadap buruh perempuan harian lepas karena alasan cuti haid, di dalam kasus tersebut telah diselesaikan dengan cara mediasi dan menghasilkan keputusan bahwa buruh perempuan harian lepas tetap dilakukan pemutusan hubungan kerja dan perusahaan wajib memberikan uang pesangon terhadap para buruh perempuan harian lepas tersebut.

Oleh karena itu, peneliti akan melakukan analisa terhadap kasus tersebut dengan memperhatikan ketentuan dalam peraturan perundang-undangan dan juga pada prakteknya.

\section{Metode Penelitian}

Tipe penelitian yang akan digunakan dalam penelitian ini adalah Penelitian Hukum Normatif dengan menggunakan pendekatan, yakni pendekatan undangundang (statute approach) yang dilakukan dengan menelaah semua undangundang dan regulasi yang bersangkut paut dengan isu hukum yang diangkat oleh peneliti. ${ }^{4}$ Selain itu, juga menggunakan pendekatan konseptual (conceptual

\footnotetext{
4 Peter Mahmud Marzuki, Penelitian Hukum (Kencana 2008).[93].
} 
approach) dimana pendekatan konseptual beranjak dari pandangan-pandangan dan doktrin-doktrin yang berkembang di dalam ilmu hukum ${ }^{5}$ serta menggunakan studi kasus atau case study yang dilakukan dengan melakukan telaah pada kasuskasus yang berkaitan dengan isu hukum yang dihadapi. ${ }^{6}$

\section{Para Pihak Dalam Hubungan Kerja}

Hubungan antara para pekerja dengan perusahaan ini adalah saling membutuhkan, yang mana di satu sisi pekerja membutuhkan perusahaan untuk tempat mereka mencari nafkah. Disisi lain perusahaan juga membutuhkan tenaga para pekerja sebagai sumber daya untuk menggerakkan perusahaan mencapai tujuan. Yang menjadi landasan hukum perikatan di dalam hubungan Industrial antara pengusaha atau pemberi kerja dengan pekerja/buruh adalah perjanjian kerja yang mana tercantum di dalam Pasal 50 UU Ketenagakerjaan bahwa "Hubungan kerja terjadi karena adanya perjanjian kerja antara pengusaha dengan pekerja/ buruh". Menurut ketentuan tersebut dapat diartikan bahwa subjek atau para pihak dalam hubungan kerja adalah pemberi kerja atau pengusaha dan pekerja/buruh.

Perjanjian kerja sendiri merupakan perjanjian yang menjelaskan tentang kerja, yang berarti dengan adanya perjanjian kerja maka timbul adanya hak dan kewajiban suatu pihak untuk melakukan suatu pekerjaan. ${ }^{7}$ Terdapat dua bentuk perjanjian kerja yaitu diucapkan secara langsung (lisan) dan berbentuk tulisan (tertulis), perjanjian kerja yang dilakukan dengan cara lisan yaitu diucapkan secara langsung antara pekerja dan pengusaha, dan perjanjian yang dilakukan secara tertulis yaitu dengan surat perjanjian yang ditandatangani oleh kedua belah pihak. Undang-undang mengatur bahwa jika perjanjian kerja dilakukan dengan cara diucapkan secara langsung (lisan), maka biaya surat dan biaya tambahan lainnya harus dibebankan pada pemberi kerja. Perjanjian kerja harus memenuhi syarat-syarat sebagai perjanjian pada umumnya, yang mana syarat-

\footnotetext{
ibid.[93].

ibid.[158].

7 Lanny Ramli, Hukum Ketenagakerjaan (Airlangga University Press 2008).[23].
} 
syarat tersebut telah diatur di dalam Pasal 1320 Kitab Undang-Undang Hukum Perdata (Burgerlijk Wetboek). Perjanjian yang dilakukan secara lisan dilakukan secara singkat dan tidak memuat semua hak dan kewajiban pengusaha/pemberi kerja maupun pekerja/buruh, sedangkan perjanjian yang dibuat secara tertulis akan berisi hak dan kewajiban pengusaha/pemberi kerja maupun pekerja/buruh. Mengenai isi perjanjian kerja tertulis, diatur di dalam Pasal 54 UU Ketenagakerjaan yaitu sekurang-kurangnya memuat :

1. Nama, alamat perusahaan dan jenis usaha;

2. Nama, Jenis Kelamin, umur dan alamat pekerja;

3. Jabatan atau jenis pekerjaan;

4. Tempat dimana pekerjaan itu dikerjakan;

5. Besarnya imbalan atau upah yang harus dibayarkan dan cara pembayaran imbalan atau upah tersebut;

6. Syarat-syarat kepada pengusaha/pemberi kerja maupun syarat-syarat terhadap pekerja/buruh yang berisi hak dan kewajiban;

7. Jangka waktu dimulainya dan berakhirnya suatu perjanjian kerja;

8. Tempat dan tanggal dimana perjanjian kerja tersebut dibuat;

9. Tanda tangan kedua belah pihak (pengusaha/pemberi kerja dan pengusaha/ buruh) di dalam perjanjian kerja.

Ketentuan-ketentuan yang telah disepakati di dalam perjanjian kerja tidak boleh bertentangan dengan apa yang ada di dalam peraturan perusahaan, maupun peraturan perundang-undangan yang berlaku.

Hubungan kerja antara pekerja/buruh dengan pengusaha atau pemberi kerja dibedakan menjadi dua yaitu hubungan kerja yang bersifat tetap dan hubungan kerja yang bersifat tidak tetap. Dalam hubungan kerja yang bersifat tetap, perjanjian kerja yang dibuat dan disepakati oleh pekerja/buruh dengan pengusaha atau pemberi kerja tersebut dengan dasar perjanjian kerja untuk waktu tidak tertentu (PKWTT). Sedangkan dalam hubungan kerja yang bersifat tidak tetap, perjanjian kerja yang dibuat dan disepakati oleh pekerja/buruh dengan pengusaha atau pemberi kerja tersebut dengan dasar perjanjian kerja waktu tertentu (PKWT).

PKWT ini merupakan hubungan kerja yang bersifat sementara seperti yang disebutkan pada Pasal 1 angka 1 Kepmenaker 100/2004. PKWT merupakan suatu perjanjian kerja dimana perjanjian kerja tersebut dibuat dan disepakati antara pekerja/buruh dengan pengusaha guna melakukan suatu pekerjaan yang 
Ferdy Dwiyanda: Pemutusan Hubungan Kerja...

diperkirakan selesai dalam waktu tertentu yang relatif pendek serta jangka waktu yang diberikan tidak lebih dari 2 tahun, perjanjian tersebut bisa diperpanjang dengan satu kali yang mana ketentuan perpanjang paling lama sama dengan waktu perjanjian kerja pertama, dengan ketentuan seluruh (masa) perjanjian tidak boleh melebihi tiga tahun lamanya. PKWT juga merupakan perjanjian yang bersyarat disebut demikian karena perjanjian PKWT memiliki syarat-syarat tertentu, yang mana syarat-syat tertentu tersebut antara lain harus dibuat tertulis dalam bahasa Indonesia, dan juga terdapat ancaman apabila tidak dibuat secara tertulis serta tidak dibuat dengan menggunakan bahasa Indonesia maka dinyatakan (dianggap) sebagai PKWTT (Pasal 57 ayat (2) UU Ketenagakerjaan). PKWT juga tidak boleh dipersyaratkan adanya masa percobaan (probation), dan jika pada perjanjian tersebut diadakan (klausul) masa percobaan dalam PKWT tersebut, maka klausula tersebut dianggap tidak pernah ada atau batal demi hukum pernyataan tersebut terdapat pada Pasal 58 UU Ketenagakerjaan. ${ }^{8}$

Di dalam Kepmenaker 100/2004 tersebut mengatur juga mengenai Perjanjian Kerja Harian Lepas. Dengan demikian, Perjanjian Kerja Harian Lepas menurut yang diatur dalam Kepmenaker ini merupakan bagian dari PKWT sebagaimana yang diatur di dalam Pasal 10 sampai dengan Pasal 12 Kepmenaker 100/2004. Kepmenaker 100/2004 juga menjelaskan Pekerja Harian Lepas merupakan pekerja dengan perjanjian waktu tertentu (PKWT). Sehingga, hak-hak tenaga kerja harian lepas adalah sebagaimana juga dengan para pekerja PKWT, yakni mendapatkan upah dan kesejahteraan. Namun, sistem upah untuk Perjanjian Kerja Harian Lepas berdasarkan pada kehadiran pekerja. Dalam hal ini pekerja/buruh harian lepas memiliki perjanjian kerja harian lepas dilakukan berdasarkan pekerja/ buruh melakukan suatu pekerjaan tersebut tidak lebih dari 21 (dua puluh satu) hari dalam 1 (satu) bulan. Dan apabila pekerja/buruh melakukan suatu pekerjaan lebih dari 21 (dua puluh satu) hari selama 3 (tiga) bulan tanpa henti atau melebihi maka perjanjian kerja harian lepas berubah dan dapat disebut sebagai PKWTT.

${ }^{8}$ Fisa van Iman, Perlindungan Hukum Terhadap Tenaga Kerja Harian Lepas Dengan Badan Penyelenggara Jaminan Sosial (BPJS Ketenagakerjaan) (Fakultas Hukum Universitas Airlangga 2015).[15]. 


\section{Pelaksanaan Pengaturan Cuti Haid Dalam Hubungan Ketenagakerjaan} Terhadap Pekerja/Buruh Perempuan Harian Lepas di Perusahaan

UU Ketenagakerjaan melindungi semua tenaga kerja perempuan untuk menjamin atas hak-hak dasar yang harus dipenuhi oleh pengusaha/pemberi kerja dan memberikan jaminan tanpa adanya diskriminasi yang mana hal tersebut memberikan kesempatan serta perlakuan yang sama, hal ini bertujuan untuk terwujudnya kesejahteraan kepada para pekerja/buruh perempua beserta keluarga pekerja/buruh tersebut.

Beberapa bentuk perlindungan hukum terhadap pekerja/buruh perempuan yaitu meliputi:

1. Perlindungan Jam Kerja

Perlindungan kerja malam untuk pekerja/buruh perempuan telah dijelaskan di dalam Pasal 76 UU ketenagakerjaan yang menyatakan bahwa:

Ayat (1): "Pekerja/buruh perempuan yang berumur kurang dari 18 (delapan belas) tahun dilarang dipekerjakan antara pukul 23.00 sampai dengan pukul 07.00".

Ayat (2): "Pengusaha dilarang mempekerjakan pekerja/buruh perempuan hamil yang menurut keterangan dokter berbahaya bagi kesehatan dan keselamatan kandungannya maupun dirinya apabila bekerja antara pukul 23.00 sampai dengan pukul 07.00".

Ayat (3): "Pengusaha yang mempekerjakan pekerja/buruh perempuan antara pukul 23.00 sampai dengan pukul 07.00, wajib memberikan makanan dan minuman bergizi; dan Menjaga kesusilaan dan keamanan selama di tempat kerja".

Ayat (4): "Pengusaha wajib menyediakan angkutan antar jemput bagi pekerja/buruh perempuan yang berangkat dan pulang antara pukul 23.00 sampai dengan pukul 05.00".

Ayat (5): "Ketentuan sebagaimana dimaksud dalam ayat (3) dan (4) diatur dengan Keputusan Menteri".

Perlindungan jam kerja kepada pekerja perempuan juga diatur lebih lanjut di dalam Pasal 77 ayat (2) yaitu "pengusaha atau pemberi kerja dilarang mempekerjakan pekerja perempuan melebihi 7 (tujuh) jam sehari dan 40 (empat puluh) jam seminggu untuk 6 (enam) hari kerja dalam seminggu atau 8 (delapan) jam sehari dan 40 (empat puluh) jam seminggu untuk 5 (lima) hari kerja dalam seminggu." Bila dikira pekerjaan yang dikerjakan memerlukan waktu yang 
cukup banyak, maka harus mendapatkan suatu persetujuan terlebih dahulu dari pekerja/buruh yang bersangkutan dan hanya dapat dilakukan tidak lebih dari 3 (tiga) jam dalam satu hari dan 14 (empat belas) jam dalam satu minggu, dengan kewajiban pengusaha/pemberi kerja membayarkan upah kepada pekerja/buruh atas kerja yang dilakukan melebihi dari jam kerja (lembur) sebagaimana yang diatur di ketentuan Pasal 78 ayat (1) dan ayat (2). Akan tetapi dalam dewasa ini, tidak sedikit perusahaan yang tidak melaksanakan ketentuan terkait pemberian makanan dan minuman bergizi untuk para pekerja/buruh yang bekerja melebihi jam kerja akan tetapi pengusaha/pemberi kerja menggantinya dengan uang.

2. Perlindungan Selama Cuti Hamil Dan Melahirkan

Hak-hak yang dimiliki seorang pekerja/buruh perempuan tidak dapat dibatasi ataupun dihilangkan dengan berdasarkan fungsi reproduksi perempuan, UU Ketenagakerjaan telah mengatur tentang perlindungan terhadap perempuan yang sedang hamil yakni antara lain:

a) Cuti hamil, keguguran dan melahirkan

Pasal 82 UU Ketenagakerjaan menyatakan bahwa:

Ayat (1): "Pekerja/buruh perempuan berhak memperoleh istirahat selama 1,5 (satu setengah) bulan sebelum satnya melahirkan anak dan 1,5 (satu setengah) bulan sesudah melahirkan menurut perhitungan dokter kandungan atau bidan"

Ayat (2): "Pekerja/buruh perempuan yang mengalami keguguran kandungan berhak memperoleh istirahat 1,5 (satu setengah) bulan sesuai dengan surat keterangan dokter kandungan atau bidan"

Pemerintah telah membuat suatu kebijakan dengan memberikan hak cuti hamil kepada para pekerja/buruh perempuan karena perempuan memiliki kodrat untuk hamil. Perlindungan hukum kepada pekerja perempuan yang sedang mengambil hak cuti hamil yaitu dengan memberikan cuti selama 1,5 (satu setengah) bulan sebelum melahirkan dan 1,5 (satu setengah) bulan setelah melahirkan tanpa mengurangi jumlah upah yang seharusnya diterima. Tidak hanya itu saja, hak cuti untuk pekerja/ buruh perempuan yang mengalami keguguran atas kehamilannya juga 
memiliki hak mendapatkan istirahat 1,5 (satu setengah) bulan yang mana hal ini dibuktikan dengan surat keterangan dari dokter. Ketentuan tersebut tidak harus menggunakan mekanisme seperti itu, akan tetapi pekerja/ buruh perempuan dapat mengatur pengambilan hak cuti hamilnya, seperti mengambil satu minggu atau dua minggu sebelum melahirkan dan sisanya diambil digabungkan dengan setelah melahirkan, jadi hak dari pekerja/ butuh perempuan tersebut tetaplah 3 bulan cuti haid, hal ini diperjanjikan terlebih dahulu di suatu perjanjian kerja dan apabila cuti tahunan bertepatan dengan pada saat pekerja/buruh perempuan mengambil hak cuti hamil maka cuti tahunannya tetap berlaku. Dalam kenyataannya masih ada perusahan yang tidak membayar upah kepada pekerja/buruh perempuan yang sedang hamil secara penuh.

b) Pekerja/Buruh Perempuan yang sedang hamil tidak dapat dilakukan pemutusan hubungan kerja (PHK)

Sudah menjadi kodrat seorang perempuan saat ia menikah, hamil, maupun melahirkan. Sehingga suatu perusahaan tidak bisa menjadikan alasan hamil dan melahirkan kepada pekerja perempuan untuk memaksa mengundurkan diri atau Pemutusan Hubungan Kerja (PHK) baik di dalam hubungan kerja PKWTT maupun hubugan kerja PKWT, hal ini sebagaimana termuat dalam Pasal 2 Peraturan Menteri Tenaga Kerja Republik Indonesia Nomor: Per-03/MEN/1989 Tentang Larangan Pemutusan Hubungan Kerja (PHK) Bagi Pekerja Wanita Karena Menikah, Hamil dan Melahirkan (yang selanjutnya disebut PERMENAKER 03/1989). Hal ini merupakan konsekuensi logis dengan diratifikasinya Konvensi ILO Nomor 111 tentang Diskriminasi dalam pekerjaan dan jabatan.

c) Tidak mengurangi hak kepada pekerja/buruh perempuan yang dialihkan tugasnya

Pekerja/buruh perempuan yang sedang hamil wajib alih tugas oleh pengusaha/pemberi kerja karena sifat dan jenis pekerjaan yang tidak dimungkinkan dikerjakan oleh peekerja/buruh perepuman yang sedang 
hamil tanpa membatasi atau mengurangi hak-hak pekerja/buruh prempuan tersebut (ketentuan Pasal 3 PERMENAKER 03/1989) dan jika pekerja/ buruh perempuan yang sedang hamil tidak dilaksanakan pengalihan tugas oleh perusahaan maka perusahaan wajib memberikan hak cuti hamil serta cuti melahirkan dan setelah pekerja/buruh perempuan tersebut melahirkan perusahaan wajib mempekerjakan kembali pekerja/buruh perempuan tersebut pada tempat dan jabatan yang sama tanpa mengurangi hak-hak pekerja perempuan tersebut (ketentuan Pasal 4 PERMENAKER 03/1989).

3. Tersedia lokasi menyusui untuk pekerja/buruh perempuan

Pekerja/buruh perempuan yang masih memiliki anak berusia balita yang masih menyusu harus disediakan kesempatan yang layak untuk menyusui anak tersebut, meskipun hal tersebut dilakukan oleh pekerja/buruh perempuan di waktu kerja. Pemerintah telah memberikan hak kepada pekerja/buruh perempuan untuk menyusui anaknya, sebagaimana yang diatur di dalam ketentuan Pasal 83 UU Ketenagakerjaan .

Aturan tersebut selain diatur di dalam UU Ketenagakerjaan juga diatur di dalam ketentuan Peraturan Bersama Menteri Negara Pemberdayaan Perempuan, Menteri Tenaga Kerja dan Transmigrasi, dan Menteri Kesehatan nomor: 48/MEN. PP?XII/2008, nomor: Per.27/MEN/XII/2008, dan nomor. 1177/Menkes/PP/PB/ XII/ 2008 Tentang Peningkatan Pemberian Air Susu selama waktu kerja di tempat kerja. Peraturan bersama ini dibuat karena mempertimbangkan bahwa setiap perempuan yang sudah menjadi seorang ibu wajib memberikan air susu kepada anaknya, dan setiap anak memiliki hak tumbuh dan berkembang secara optimal baik fisik, mental spiritual, maupun kecerdasan.

4. Perlindungan kepada pekerja/buruh perempuan saat masa haid

Masa haid adalah salah satu masa reproduksi perempuan yang dirasakan setiap satu bulan sekali yang mana haid merupakan pendarahan dari rahim dan merupakan satu kriterium dari seorang perempuan. ${ }^{9}$

9 Sali Susiana, 'Perlindungan Hak Pekerja Perempuan Dalam Perspektif Feminisme' [2017] Pusat Penelitian Badan Keahlian DPR RI. [211]. 
Terdapat 2 (dua) yang jenis haid yang akan dirasakan oleh seorang perempuan di setiap bulannya yaitu haid yang tidak normal dan haid yang normal. Untuk haid yang normal adaalah haid yang tidak disertai dengan rasa sakit, sedangkan haid yang tidak normal adalah haid yang disertai rasa sakit sehinggal menyebabkan pekerja/buruh perempuan tidak dapat bekerja. Dalam masa haid, perempuan akan merasakan penurunan kapasitas daya dan ketahanan kesabaran sebesar $10 \%$ setiap mengalami haid. Maka dari itu pekerja/buruh perempuan berhak mendapatkan perlindungan hukum dalam masa haidnya.

Pasal 81 UU Ketenagakerjaan telah mengatur tentang perlindungan hukum kepada pekerja perempuan yang sedang mengalami masa haid bahwa:

Ayat (1): "Pekerja/buruh perempuan yang dalam masa haid merasakan sakit dan memberitahukan kepada pengusaha, tidak wajib bekerja pada hari pertama dan kedua pada waktu haid."

Ayat (2): "Pelaksanaan ketentuan sebagaimana dimaksud dalam ayat (1) diatur dalam perjanjian kerja, peraturan perusahaan, atau perjanjian kerja bersama."

Dalam pasal tersebut terdapat 2 (dua) syarat pengambilan hak cuti haid yaitu yang pertama adalah hak cuti haid dapat diambil jika pekerja/buruh perempuan merasakan rasa sakit pada masa haidnya, hal ini dapat dibuktikan dengan surat keterangan dari dokter yang kemudian diberitahukan kepada pengusaha atau pemberi kerja. Syarat yang kedua adalah hak cuti haid hanya dapat diperoleh jika diatur di dalam perjanjian kerja, peraturan perusahaan, atau perjanjian kerja bersama.

\section{Pemutusan Hubungan Kerja (PHK) Terhadap Pekerja/Buruh Harian Lepas Karena Cuti Haid}

Pemutusan Hubungan Kerja (PHK) tidak dapat dilakukan dengan sewenangwenang oleh perusahaan, dalam Pasal 153 UU Ketenagakerjaan telah menentukan alasan-alasan yang tidak boleh dijadikan dasar permohonan penetapan PHK, antara lain :

1. Pekerja/buruh yang berhalangan bekerja karena sakit menurut keterangan dokter selama waktu tidak melampaui 12 (dua belas) bulan secara terus 
Ferdy Dwiyanda: Pemutusan Hubungan Kerja...

menerus;

2. Pekerja/buruh tidak dapat menjalankan pekerjaannya karena memenuhi kewajiban terhadap negara sesuai dengan ketentuan peraturan perundangundangan;

3. Pekerja/buruh yang sedang menjalankan ibadah agamanya;

4. Pekerja/buruh menikah;

5. Pekerja/buruh perempuan yang sedang hamil, melahirkan, gugur kandungan, atau menyusui anaknya;

6. Pekerja/buruh yang mempunyai pertalian darah dan/atau ikatan perkawinan dengan pekerja/buruh lainnya di suatu perusahaan, kecuali telah disepakati di suatu perjanjian kerja, peraturan perusahaan, atau perjanjian kerja bersama;

7. Pekerja/buruh mendirikan, menjadi anggota/pengurus serikat pekerja, melakukan kegiatan serikat pekerja di luar atau di dalam jam kerja atas kesepakatan pengusaha, berdasarkan ketentuan dalam perjanjian kerja, peraturan perusahaan, atau perjanjian kerja bersama;

8. Pekerja/buruh yang mengadukan pengusaha atau pemberi kerja kepada pihak yang berwajib atas perbuatan pengusaha atau pemberi kerja yang melakukan tindak pidana kejahatan;

9. Pekerja/buruh yang memiliki perbedaan paham, agama, aliran politik, suku, warna kulit, golongan, jenis kelamin, kondisi fisik, atau status perkawinan;

10. Pekerja/buruh dalam keadaan cacat tetap, sakit akibat kecelakaan kerja, atau sakit karena hubungan kerja yang menurut surat dokter jangka waktu penyembuhannya belum dapat dipastikan.

Dari penjelasan dan ketentuan-ketentuan diatas berlaku kepada seluruh tenaga kerja yang memiliki hubungan kerja PKWTT maupun yang memiliki hubungan kerja PKWT.

Apabila terjadi pemutusan hubungan kerja dengan alasan yang tertera di atas, maka menurut Pasal 153 ayat (2) UU Ketenagakerjaan PHK tersebut batal demi hukum dan pengusaha atau pemberi kerja wajib mempekerjakan kembali pekerja/ buruh yang bersangkutan. Batal demi hukum yang dimaksud adalah pemutusan hubungan kerja tersebut dianggap tidak pernah ada atau dapat diartikan tidak sah karena tidak terpenuhinya syarat objektif, batal demi hukum beda halnya dengan "dapat dibatalkan" yang memliki arti bahwa suatu hal tersebut 'ada' akan tetapi hal tersebut dapat dibatalkan oleh salah satu pihak jika salah satu pihak tersebut merasa keberatan atau merasa dirugikan.

Dalam hal pemutusan hubungan kerja terhadap pekerja PKWTT maupun PKWT tetap dilakukan, pengusaha atau pemberi kerja wajib membayar uang 
pesangon dan atau uang penghargaan masa kerja dan uang penggantian hak yang seharusnya diterima sesuai yang diatur dalam Pasal 156 UU Ketenagakerjaan dan apabila pemutusan hubungan kerja dilakukan terhadap pekerja PKWT sebelum berakhirnya jangka waktu yang ditetapkan dalam perjanjian kerja waktu tertentu tersebut, pengusaha atau pemberi kerja wajib membayar ganti rugi kepada pekerja sebesar upah pekerja/buruh sampai batas waktu berakhirnya jangka waktu perjanjian kerja, hal ini telah diatur dalam ketentuan yang diatur dalam Pasal 62 UU Ketenagakerjaan.

Menurut penjelasan di atas jika disesuaikan dengan kasus yang terjadi di PT. PEI HAI Kabupaten Jombang maka pekerja/buruh perempuan harian lepas yang sedang mengambil cuti dalam masa haid dapat dilakukan pemutusan hubungan kerja selama pengambilan cuti tersebut tidak diatur/disepakati di dalam suatu perjanjian kerja, peraturan perusahaan, atau perjanjian kerja bersama. Namun jika pengambilan cuti dalam masa haid telah diatur dalam perjanjian kerja, peraturan perusahaan, atau perjanjian kerja bersama, perusahaan tidak dapat melakukan pemutusan hubungan kerja terhadap pekerja/buruh perempuan harian lepas tersebut karena pekerja/buruh perempuan harian lepas yang mengambil cuti dalam masa haid, karena disertai rasa sakit (dibuktikan menggunakan surat keterangan dokter) juga termasuk di dalam alasan yang tidak diperbolehkan untuk dilakukan pemutusan hubungan kerja yang telah diatur di dalam Pasal 153 angka 1 UU Ketenagakerjaan serta diatur lebih jelas hak pengambilan cuti pada masa haid di dalam Pasal 81 UU Ketenagakerjaan.

\section{Penyelesaian Hubungan Industrial di Perusahaan}

Dalam Pasal 1 angka 22 UU Ketenagakerjaan jo. Pasal 1 angka 1 UndangUndang Nomor 2 tahun 2004 tentang Penyelesaian Perselisihan Hubungan Industrial dirumuskan pengertian perselisihan hubungan industrial yaitu “Perbedaan pendapat yang mengakibatkan pertentangan antara pengusaha atau gabungan pengusaha dengan pekerja/buruh atau serikat pekerja/serikat buruh, karena adanya perselisihan mengenai hak, perselisihan kepentingan dan 
perselisihan pemutusan hubungan kerja serta perselisihan antara serikat pekerja/ serikat buruh hanya dalam satu perusahaan". Dari penjelasan Pasal tersebut, terdapat unsur-unsur dari perselisihan yaitu:

a. Adanya pihak dalam perselisihan;

b. Terdapat tujuan yang tidak sama, yakni salah satu pihak memiliki tujuan yang harus pihak yang lain berbuat sesuai kemauannya;

c. Keinginan salah satu pihak tidak sama dengan keinginan dari pihak yang lainnya. ${ }^{10}$

Selanjutnya, dalam Pasal 2 Undang-Undang Nomor 2 Tahun 2004 tentang Penyelesaian Perselisihan Hubungan Industrial (yang selanjutnya disebut UU PPHI) menyebutkan beberapa jenis perselisihan hubungan industrial, yakni: ${ }^{11}$

1. Perselisihan hak;

2. Perselisihan kepentingan;

3. Perselisihan pemutusan hubungan kerja;

4. Perselisihan antar serikat pekerja/serikat buruh.

Perselisihan antara pekerja/buruh dengan pengusaha yang tidak dapat diselesaikan dengan cara musyawarah akan diselesaikan di Pengadilan Hubungan Industrial, Pengadilan hubungan industrial bertugas dan berwenang memeriksa dan memutus mengenai hubungan industrial sebagaimana yang jelaskan di ketentuan Pasal 56 UU PPHI yakni:

1. Di tingkat pertama mengenai perselisihan hak;

2. Di tingkat pertama dan terakhir mengenai perselisihan kepentingan;

3. Di tingkat pertama mengenai perselisihan pemutusan hubungan kerja;

4. Di tingkat pertama dan terakhir mengenai perselisihan antara serikat pekerja/ serikat buruh dalam satu perusahaan.

Meskipun berstatus sebagai pekerja waktu tertentu, tidak menutup kemungkinan untuk pekerja harian lepas dapat berperkara didalam pengadilan hubungan industrial dikarenakan hak-hak pekerja harian lepas masih berada

${ }^{10}$ Lalu Husni, Penyelesaian Hubungan Industrial Melalui Pengadilan $\mathcal{E}$ Di Luar Pengadilan (Raja grafindo Persada 2004).[3].

11 Ujang Charda S, 'Model Penyelesaian Perselisihan Hubungan Industrial Dalam Hukum Ketenagakerjaan Setelah Lahirnya Undang-Undang Nomor 2 Tahun 2004' (2017) 1 Jurnal Wawasan Yuridika Fakultas Hukum Universitas Subang.[8]. 
dibawah perlindungan hukum pemerintah. Telah dijelaskan di bab sebelumnya bahwa dalam perjanjian kerja harian lepas merupakan PKWT maka dapat dimungkinkan pekerja tersebut mendapatkan perlindungan hukum seperti pekerja lainnya termasuk dalam hubungan industrial dan berperkara di pengadilan hubungan industrial.

Menurut UU PPHI, penyelesaian perselisihan hubungan industrial dapat menggunakan melalui 2 (dua) jalur untuk menyelesaikan, yaitu:

1. Dengan cara melimpahkan masalah perselisihan tersebut kepada seorang ahli sebagai penengah. Penyelesaian seperti ini biasa disebut dengan penyelesaian sukarela (voluntary arbitration), yaitu dapat melalui mediasi, konsiliasi, dan arbitrase.

2. Dengan cara menyerahkan masalah perselisihan ini kepada Pengadilan Hubungan Industrial yang mana permasalahan ini akan diselesaikan dengan berlandaskan peraturan perundang-undangan yang berlaku. ${ }^{12}$

Setiap perselisihan hubungan industrial harus dilakukan terlebih dahulu dengan cara perundingan oleh kedua belah pihak atau biasa disebut dengan Bipartit. Para pihak dalam bipartit ini terdiri dari perwakilan pengusaha dan perwakilan pekerja dan atau serikat pekerja/serikat buruh. Dalam UU Ketenagakerjaan Pasal 106 telah mengatur bahwa " perusahaan untuk membentuk lembaga bipartit apabila mempekerjakan 50 (lima puluh) orang pekerja/buruh atau lebih", kemudian disebutkan juga dalam ayat (2) bahwa "lembaga kerja sama bipartit sebagaimana dimaksud dalam ayat (1) berfungsi sebagai forum komunikasi, dan konsultasi mengenai hal ketenagakerjaan di perusahaan." Dengan adanya ketentuan tersebut maka akan lebih meminimalisir adanya perselisihan hubungan industrial antara pekerja/buruh dengan pengusaha. Apabila telah terjadi perselisihan hubungan industrial, maka telah diatur langkah-langkah selanjutnya yang harus diambil. Dalam Pasal 3 UU PPHI, yang menentukan sebagai berikut: ${ }^{13}$

12 ibid.[13].

${ }^{13}$ Arum Setiyoningsih, Perlindungan Hukum Pada Pekerja/Buruh Harian Lepas Dalam Pemberian Jaminan Sosial Di Perusahaan (Fakultas Hukum Universitas Airlangga 2018).[71-72]. 
Ferdy Dwiyanda: Pemutusan Hubungan Kerja...

Ayat (1): "Perselisihan hubungan industrial wajib diupayakan penyelesaiaannya terlebih dahulu melalui perundingan bipartit secara musyawarah untuk mencapai mufakat".

Ayat (2): "Penyelesaian perselisihan melalui bipartit sebagaimana dimaksud dalam ayat (1), harus diselesaikan paling lama 30 (tiga puluh) hari kerja sejak tanggal dimulainya perundingan".

Ayat (3) : "Apabila dalam jangka waktu 30 (tiga puluh) hari sebagaimana dimaksud dalam ayat (2) salah satu pihak menolak untuk berunding atau telah dilakukan perundingan tetapi tidak mencapai kesepakatan, maka perundingan bipatrit dianggap gagal".

Kesepakatan yang dicapai di dalam proses bipartit dituangkan dalam bentuk kesepakatan bersama dan ditandatangani oleh para pihak yang berselisih. Salah satu pihak dapat mengajukan permohonan penetapan eksekusi kepada Pengadilan Hubungan Industial Bila salah satu pihak tidak melaksanakan kesepakatan tersebut. ${ }^{14}$

Apabila secara bipartit gagal, tahap selanjutnya adalah penyelesaian dengan cara tripartit. Penyelesaian tripatit ini melibatkan lembaga kerjasama tipartit dimana pemerintah merupakan salah satu yang memiliki andil di dalamnya, dan di dalam Pasal 107 Undang-undang Ketenagakerjaan yang menegaskan bahwa "keanggotaan lembaga kerja sama tripartit terdiri atas unsur pemerintah, organisasi pengusaha, dan serikat pekerja/serikat buruh." berdasarkan Pasal 4 UU PPHI menyatakan sebagai berikut: ${ }^{15}$

Ayat (1): "Dalam hal perundingan bipartit gagal sebagaimana dimaksud dalam Pasal 3 ayat (3), maka salah satu atau kedua belah pihak mencatatkan perselisihannya kepada instansi yang bertanggung jawab di bidang ketenagakerjaan setempat dengan melampirkan bukti bahwa upaya-upaya penyelesaian melalui perundingan bipartit telah dilakukan".

Ayat (2): "Apabila bukti-bukti sebagaimana dimaksud dalam ayat (1) tidak dilampirkan, maka instansi yang bertanggung jawab di bidang ketenagakerjaan mengembalikan berkas untuk dilengkapi paling lambat dalam waktu 7 (tujuh) dari kerja terhitung sejak tanggal diterimanya pengembalian berkas".

Ayat (3) : "Setelah menerima pencatatan dari salah satu atau para pihak,

14 Ujang Charda S (n 11)., Op.Cit.[14].

${ }^{15}$ Arum Setiyoningsih (n 13)., Op.Cit.[73-74]. 
instansi yang bertanggung jawab di bidang ketenagakerjaan setempat wajib menawarkan kepada para pihak untuk menyepakati memilih penyelesaian melalui konsilasi atau melalui arbitrase".

Ayat (4): "Dalam hal para pihak tidak menetapkan pilihan penyelesaian melalui konsiliasi atau arbitrase dalam waktu 7 (tujuh) hari kerja, makainstansiyang bertanggungjawab dibidang ketenagakerjaan melimpahkan penyelesaian perselisihan kepada mediator".

Ayat (5) : "Penyelesaian melalui konsilisasi dilakukan untuk penyelesaian perselisihan kepentingan, perselisihan pemutusan hubungan kerja, atau perselisihan antar serikat pekerja/serikat buruh".

Ayat (6) : "Penyelesaian melalui arbitrase dilakukan untuk penyelesaian perselisihan kepentingan atau perselisihan antar serikat pekerja/ serikat buruh".

Penyelesaian perselisihan hubungan industrial secara tripartit atau melibatkan orang ketiga diluar pihak yang berperkara terdapat berbagai macam yang terdiri dari:

1. Penyelesaian melalui Mediasi oleh Mediator

Dalam Pasal 8 UU PPHI penyelesaian perselisihan melalui mediasi dilakukan oleh mediator yang ada di setiap kantor pemerintah yang bertanggung jawab di bidang ketenagakerjaan. Proses mediasi dilakukan selambat-lambatnya dilakukan 7 (tujuh) hari kerja setelah menerima penyerahan penyelesaian perselisihan hubungan industrial, mediator telah melaksanakan sebuah penelitian/pencarian terkait alur masalah dan sidang mediasi telah diadakan oleh mediator. Mediator yang terpilih wajib menyelesaikan tugasnya dalam waktu paling lambat 30 (tiga puluh) hari kerja sejak dilimpahkan penyelesaian perselisihan hubungan industrial tersebut kepada mediator. ${ }^{16}$

2. Penyelesaian melalui Konsiliasi oleh Konsiliator

Konsiliator adalah anggota masyarakat yang telah berpengalaman di bidang hubungan industrial dan menguasai peraturan perundang-undangan ketenagakerjaanyang ditunjuk oleh Menteri untuk melakukan konsiliasi dan anjuran tertulis kepada pengusaha dan pekerja/buruh atau serikat pekerja/

${ }^{16}$ Andi Fariana, Aspek Legal Sumber Daya Manusia Menurut Hukum Ketenagakerjaan (Mitra Wacana Media 2012).[49]. 
serikat buruh yang mana hal tersebut bertujuan menyelesaikan perselisihan kepentingan dan perselisihan pemutusan hubungan kerja. Konsiliator harus menyelesaikan satu kasus perselisihan paling lambat dalam waktu 40 (empat puluh) hari. Penyelesaian perselisihan melalui konsiliasi oleh konsiliator diatur dalam Pasal 17 UU PPHI.

3. Penyelesaian melaui Arbitrase oleh Arbiter

Arbitrase merupakan proses pemeriksaan sengketa yang dikehendaki para pihak yang termasuk dalam perselisihan yang mana proses tersebut dilakukan secara yudisial dan penyelesaiannya berdsarkan dari bukti-bukti yang diajukan oleh para pihak. ${ }^{17}$ Berdasarkan Pasal 29 UU PPHI menyatakan bahwa "Penyelesaian perselisihan hubungan industrial melalui arbitrase meliputi perselisihan kepentingan dan perselisihan antar serikat pekerja/ serikat buruh hanya dalam satu perusahaan. Putusan yang dikeluarkan melalui arbitrase akan mengikat para pihak yang bersengketa".

Upaya hukum terakhir dalam perselisihan hubungan industrial adalah dengan mengajukan permohonan gugatan ke pengadilan hubungan industrial, dalam hal ini pekerja harian lepas yang mengikuti PKWT dapat mengajukan gugatan ke pengadilan hubungan industrial sampai pada tingkat kasasi. Pada dasarnya sesuai dengan hukum perundang-undangan mengenai ketengakerjaan yang berlaku pada pekerja harian lepas, pekerja harian lepas dapat menuntut ke pengadilan hubungan industrial apabila pekerja tersebut merasa haknya telah dilanggar oleh perusahaan. ${ }^{18}$

\section{Sanksi atas Tidak Terpenuhinya Hak-Hak Pekerja/Buruh Perempuan Harian Lepas dalam Pemberian Cuti Haid}

Sama seperti pelanggaran hukum lainnya, pelanggaran dalam hukum ketenagakerjaan pun tidak lepas dari ancaman sanksi. Dalam UU Ketenagakerjaan

17 Sudiarto \& Zaeni Asyhadie, Mengenal Abitrase Salah Satu Alternatif Penyelesaian Sengketa Bisnis (Raja Grafindo Persada 2004).[28-29].

18 Arum Setiyoningsih (n 13)., Op.Cit.[76]. 
terdapat banyak pasal yang mengatur terkait sanksi atas suatu tindakan pelanggaran ketenagakerjaan. Terdapat 2 (dua) macam sanksi yang diatur di ketentuan UU Ketenagakerjaan yaitu sebagai berikut:

1. Sanksi Administrasi

KetentuansanksiadministrasitelahdiaturdidalamPasal190UUKetenagakerjaan yang mana sanksi administrasi diberikan dalam hal pelanggaran atas hal: ${ }^{19}$

a. Terdapat tindakan/perbuatan diskriminasi terkait pekerjaan (Pasal 5);

b. Terdapat tindakan/perbuatan diskriminasi yang didapatkan oleh pekerja/ buruh (Pasal 6);

c. Persyaratan dalam metelenggaraan pelatihan kerja tidak terpenuhi (Pasal 15);

d. Ketidaksesuaian terkait aturan yang mengatur tentang pemagangan di luar Indonesia (Pasal 25);

e. Ketidaksesuaian mengenai aturan yang mengatur tentang pemungutan biaya penempatan kerja (Pasal 38 Ayat (2));

f. Ketidaksesuaian tindakan perusahaan dengan aturan yang mengatur terkait mempekerjakan tenaga asing (Pasal 45 ayat (1));

g. Tenaga kerja asing yang tidak memperoleh kompensasi dari pengusaha/ pemberi kerja (Pasal 47 Ayat (1));

h. Tidak dipulangkannya tenaga kerja asing oleh pengusaha/pemberi kerja setelah masa kerja tenaga kerja asing tersebut berakhir (Pasal 48);

i. Sistem manajemen keselamatan dan kesehatan kerja yang terintegrasi dengan sistem manajemen perusahaan tidak diterapkan oleh pengusaha/ pemberi kerja (Pasal 87);

j. Tidak terbentuknya lembaga kerjasama bipartit oleh pengusaha/pemberi kerja yang sesuai aturan (Pasal 106);

k. Pekerja tidak menerima naskah perjanjian kerja bersama yang diberikan oleh pengusaha/ pemberi kerja atas biaya perusahaan (Pasal 126 ayat (3));

1. Pekerja/buruh yang tidak mendapatkan tunjangan dari pengusaha/ pemberi kerja atas ditangkapnya oleh pihak berwajib yang bukan atas dasar pelaporan dari pengusaha/ pemberi kerja(Pasal 160 ayat (1) dan (2)).

Bentuk sanksi administrasi yang diberikan kepada pelanggar menurut Pasal

190 ayat (2) adalah berupa :

1. Teguran;

2. Peringatan tertulis;

3. Pembatasan kegiatan usaha;

4. Pembekuan kegiatan usaha;

19 Thareq Akmal Hibatullah, 'Sanksi Di UU Ketenagakerjaan Yang Wajib Diketahui Oleh Pengusaha' (Smart Legal Indonesia, 2019) <https://smartlegal.id/smarticle/2019/02/27/sanksi-uu-ketenagakerjaan/>., accesed on 2 Desember 2019. 
5. Pembatalan persetujuan;

6. Pembatalan pendaftaran;

7. Penghentian sementara sebagian atau seluruh alat produksi;

8. Pencabutan ijin.

2. Sanksi Pidana

Sanksi pidana dalam hubungan industrial dapat dijatuhkan kepada pekerja/ buruh atau pengusaha / pemberi kerja apabila melakukan suatu pelanggaran dalam hubungan industrial. Bentuk pidana yang dapat dijatuhkan kepada pekerja/ buruh ataupun pengusaha/pemberi kerja yang melakukan suatu pelanggaran yakni berupa denda, kurungan, dan penjara. Sanksi pidana yang telah diatur pada UU Ketenagakerjaan pada Pasal 183 sampai Pasal 189 yakni: ${ }^{20}$

a. Dalam Pasal 183 UU Ketenagakerjaan menaytakan bahwa “Sanksi pidana penjara paling singkat 2 (dua) tahun dan paling lama 5 (lima) tahun dan/ atau denda paling sedikit Rp.200.000.000,00 (Dua ratus juta rupiah) dan paling banyak Rp500.000.000,00 (Lima ratus juta rupiah)" dijatuhkan kepada pengusaha yang mempekerjakan anak pada pekerjaan-pekerjaan yang membahayakan anak tersebut sebagaimana yang dimaksud di dalam Pasal 74 UU Ketenagakerjaan;

b. Dalam Pasal 184 UU Ketenagakerjaan menyatakan bahwa "Sanksi pidana penjara paling singkat 1 (satu) tahun dan paling lama 5 (lima) tahun dan/atau denda paling sedikit Rp100.000.000,00 (Seratus juta rupiah) dan paling banyak Rp500.000.000,00 (lima ratus juta rupiah)" dijatuhkan kepada pengusaha yang tidak mengikutsertakan pekerja dalam program pensiun di perusahaannya yang diatur dalam Pasal 167 ayat (5) UU ketenagakerjaan;

c. Dalam Pasal 185 UU Ketenagakerjaan menyatakan bahwa “Sanksi pidana penjara paling singkat 1 (satu) tahun dan paling lama 4 (empat) tahun dan/atau denda paling sedikit Rp100.000.000,00 (Seratus juta rupiah) dan paling banyak Rp400.000.000,00 (Empat ratus juta rupiah)" dijatuhkan kepada pihak yang melakukan suatu tindakan/perbuatan pelanggaran yang diatur dalam ketentuan:

20 ibid. 
1. Pengusaha/Pemberi kerja yang telah mempekerjakan tenaga kerja asing yang tidak sesuai dengan aturan (Pasal 42 ayat (1) dan (2)

2. Pengusaha/Pemberi kerja yang telah sengaja mempekerjakan seorang anak (Pasal 68)

3. Ketidaksesuaian persyaratan kepada pengusaha/Pemberi kerja yang telah mempekerjakan anak dalam pekerjaan yang ringan. (Pasal 69 Ayat (2)

4. Pekerja/buruh yang tidak diberikan kesempatan beribadah oleh pengusaha/ pemberi kerja (Pasal 80)

5. Pengusaha/pemberi kerja yang tidak memberikan istirahat yang cukup kepada pekerja/buruh perempuan yang sedang hamil (Pasal 82)

6. Pengusaha/Pemberi kerja yang telah membayar pekerja/buruh dengan upah yang dibawah upah minimum (Pasal 90 Ayat (1)

7. Pengusaha/pemberi kerja yang menghalangi pekerja/buruh untuk melakukan mogok kerja (Pasal 143 Ayat (1)

8. Pengusaha/pemberi kerja yang tidak mempekerjakan kembali pekerja/ buruh yang dalam persidangan dinyakan tidak bersalah atau pengusaha/ pemberi kerja yang tidak memberikan hak atas PHK (Pasal 160 Ayat (7)

d. Dalam Pasal 186 UU Ketenagakerjaan menaytakan bahwa "Sanksi pidana penjara paling sedikit 1 (satu) bulan dan paling lama selama 4 (empat) tahun dan/atau denda paling sedikit Rp10.000.000,00 (Sepuluh juta rupiah) dan paling banyak Rp400.000.000,00 (Empat ratus juta rupiah)." ketentuan dalam hal ini ditujukan kepada para pelanggar yang termasuk dalam ketentuan sebagai berikut:

1. Pengusaha/pemberi kerja yang tidak memberikan perlindungan kepada pekerja/buruh (Pasal 35 Ayat (2) dan (3);

2. Pengusaha/pemberi kerja tidak memberikan upah yang seharusnya diberikan kepada pekerja/buruh yang mana sesuai dengan aturan dalam Pasal 93 ayat (2).

e. Dalam Pasal 187 UU Ketenagakerjaan menyatakan bahwa "Sanksi pidana kurungan paling singkat 1 (satu) bulan dan paling lama 12 (dua belas) bulan dan/atau denda paling sedikit Rp10.000.000,00 (sepuluh juta rupiah) dan paling banyak Rp100.000.000,00 (Seratus juta rupiah)" ketentuan ini dijatuhkan kepada para pelanggar yang termasuk dalam ketentuan sebagai berikut:

1. Izin yang tidak dimiliki oleh lembaga penempatan tenaga kerja swasta (Pasal 37 ayat (2); 
2. Pengusaha atau pemberi kerja yang mempekerjakan tenaga kerja asing tidak mentaati ketentuan yang telah diatur dalam aturan (Pasal 44 ayat (1);

3. Pengusaha/pemberi kerja yang mempekerjakan tenaga kerja asing tidak melaksanakan kewajiban sesuai dengan ketentuan yang sudah diatur di dalam aturan (Pasal 45 ayat (1);

4. Pengusaha/pemberi kerja yang mempekerjakan tenaga kerja yang cacat tidak memberikan perlindungan yang seharusnya diberikan kepada tenaga kerja cacat tersebut (Pasal 67 ayat (1);

5. Pengusaha/pemberi kerja yang tidak memenuhi syarat untuk mempekerjakan anak (Pasal 71 ayat (2);

6. Pelanggaran yang di lakukan pengusaha/pemberi kerja dalam ketentuan mempekerjakan perempuan(Pasal 76);

7. Pengusaha/pemberi kerja yang tidak memberikan upah lembur kepada pekerja/buruh yang bekerja melebihi waktu jam kerja yang ditentukan (Pasal 78 ayat (2) dan Pasal 85 ayat (3);

8. Pengusaha/pemberi kerja tidak memberikan hak kepada pekerja/buruh dalam pengambilan waktu istirahat dan hak untuk cuti (Pasal 79 ayat (1) dan (2);

9. Pengusaha/pemberi kerja yang melakukan tindakan larangan yang diatur peraturan perundang-undangan mengenai mogok kerja (Pasal 144).

f. Dalam Pasal 188 UU Ketenagakerjaan menyatakan bahwa "Sanksi pidana kurungan paling singkat 1 (satu) dan paling lama 12 (dua belas) bulan dan/ atau denda paling sedikit Rp10.000.000,00 (sepuluh juta rupiah) dan paling banyak Rp100.000.000,00 (Seratus juta rupiah)" ketentuan ini dijatuhkan kepada pelaku yang melanggar dalam ketentuan sebagai berikut:

1. Tidak terdaftarnya suatu lembaga pelatihan kerja (Pasal 14 ayat (2);

2. Ketidaksesuaian dalam ketentuan mengenai pemungutan biaya yang dilakukan oleh Lembaga penempatan tenaga kerja swasta (Pasal 38 ayat (2);

3. Pengusaha/pemberi kerja yang atas tindakannya tidak membuat surat pengangkatan dalam hal PKWTT yang dibuat secara lisan (63 ayat (1);

4. Pengusaha/pemberi kerja yang tidak memenuhi syarat untuk memperkerjakan pekerja/buruh melebihi waktu kerja yang sudah ditentukan (Pasal 78 ayat (1);

5. Pengusaha/pemberi kerja yagn tidak mempunyai peraturan perusahaan dalam mempekerjakan pekerja lebih dari sepuluh orang setelah disahkan menteri atau pejabat yang ditunjuk (Pasal 108 ayat (1);

6. Pengusaha/pemberi kerja yang tidak melakukan pembaruan terhadap Peraturan perusahaan setelah jangka waktu 2 (dua) tahun (Pasal 111 ayar (3);

7. Pekerja/buurh tidak diberikan informasi atau tidak dijelaskan isi serta tidak diberikan naskah peraturan perusahaan oleh pengusaha/pemberi kerja (Pasal 114); 
8. Pengusaha/pemberi kerja tidak memberikan informasi sekurangkurangnya tujuh hari kerja sebelum ditutupnya suatu perusahaan kepada pekerja/buruh dan/atau seriakt pekerja/seikat buruh (Pasal 148).

Di dalam Pasal 81 ayat (2) UU Ketenagakerjaan menjelaskan bahwa pemberian cuti haid diberikan jika diperjanjikan di dalam suatu perjanjian kerja, maka jika hak cuti haid itu disepakati dalam suatu perjanjian kerja, peraturan perusahaan, atau perjanjian kerja bersama, maka jika perusahaan tidak memberikan hak cuti haid tersebut kepada pekerja/buruh perempuan yang sudah diperjanjikan di perjanjian kerja, peraturan perusahaan, ataupun perjanjian kerja bersama, perusahaan akan mendapatkan sanksi yang telah diatur di dalam UU Ketenagakerjaan. Sanksi yang akan didapatkan oleh perusahaan yang tidak memberikan hak cuti haid kepada pekerja/buruh perempuan yang merasakan sakit saat masa haid yang telah disepakati di perjanjian kerja, peraturan perusahaan, ataupun perjanjian kerja bersama berupa sanksiadministrasi yang diatur dalam Pasal190UU Ketenagakerjaan karena perusahaan tidak menerapkan sistem manajemen kesehatan kerja kepada pekerja/buruh perempuan tersebut sebagaimana yang di atur di dalam Pasal 81 jo. Pasal 87 UU Ketenagakerjaan, dan sanksi pidana dalam ketentuan Pasal 187 UU Ketenagakerjaan karena perusahaan tidak memberikan masa cuti haid kepada pekerja/buruh perempuan yang merasakan sakit pada masa haidnya yang mana diatur di dalam Pasal 81 jo. Pasal 79 ayat (1) UU ketenagakerjaan.

Perusahaan yang melakukan pemutusan hubungan kerja kepada pekerja/ buruh perempuan yang sedang mengambil cuti haid karena merasakan sakit pada masa haidnya dan telah diperjanjikan di perjanjian kerja, peraturan perusahaan,ataupun perjanjian kerja bersama, maka sesuai dengan Pasal 153 UU Ketenagakerjaan pemutusan hubungan kerja tersebut batal demi hukum dan pengusaha wajib memperkerjakan kembali pekerja/buruh perempuan tersebut atau jika tetap terjadi pemutusan hubungan kerja maka perusahaan wajib memberikan hak atas pemutusan hubungan kerja yang telah diatur dalam Pasal 156 UU Ketenagakerjaan. Jika perusahaan tidak mempekerjakan kembali pekerja/buruh perempuan tersebut atau tidak memberikan hak atas pemutusan hubungan kerja 
sabagaimana yang dijelaskan dalam Pasal 160 ayat (4) dan (7), maka perusahaan dijatuhkan sanksi pidana yang diatur dalam Pasal 185 UU Ketenagakerjaan.

Jika disesuaikan dengan kasus PT PEI HAI di Kabupaten jombang, dalam kasus tersebut pekerja/buruh perempuan harian lepas PT PEI HAI telah melakukan upaya hukum jalur non litigasi tripartit yaitu melalui mediasi yang mana mediasi tersebut menghasilkan keputusan bahwa pekerja/buruh perempuan harian lepas PT PEI HAI tetap dilakukan pemutusan hubungan kerja dan perusahaan seharusnya wajib memberikan uang ganti rugi kepada pekerja/ buruh perempuan harian lepas tersebut sebesar upah pekerja/buruh sampai batas waktu berakhirnya jangka waktu perjanjian kerja karena pemutusan hubungan kerja tersebut dilakukan kepada pekerja/buruh harian lepas yang merupakan hubungan kerja PKWT.

\section{Kesimpulan}

Dalam Pasal 81 Undang-Undang Nomor 13 Tahun 2003 tentang Ketenagakerjaan, Perusahaan yang mempekerjakan tenaga kerja perempuan dapat memberikan cuti pada masa haid pekerja/buruh perempuan tersebut yang disertai dengan rasa sakit (dibuktikan menggunakan surat keterangan dokter) di hari pertama dan kedua masa haid, termasuk pekerja/buruh perempuan harian lepas. Ketentuan ini dapat dilaksanakan jika diatur di dalam perjanjian kerja, peraturan perusahaan, atau perjanjian kerja bersama. Perusahaan yang telah memberikan hak cuti haid kepada pekerja/buruh perempuan yang dituangkan di dalam perjanjian kerja, peraturan perusahaan, atau perjanjian kerja bersama tidak dapat melakukan pemutusan hubungan kerja karena alasan cuti haid. Jika pemberian cuti haid tidak diatur dalam perjanjian kerja, peraturan perusahaan, atau perjanjian kerja bersama, perusahaan dapat melakukan pemutusan hubungan kerja terhadap pekerja/buruh perempuan harin lepas yang tidak masuk kerja dengan alasan cuti haid. Apabila perusahaan atau pemberi kerja melakukan pemutusan hubungan kerja kepada pekerja/buruh perempuan karena alasan cuti haid yang disertai rasa sakit pada masa haidnya dan telah diatur dalam perjanjian kerja, peraturan perusahaan, atau 
perjanjian kerja bersama, maka pemutusan hubugan kerja tersebut batal demi hukum dan perusahaan atau pemberi kerja wajib mempekerjakan kembali pekerja/ buruh perempuan tersebut. Dan jika pemutusan hubungan kerja tetap terjadi, maka perusahaan wajib membayarkan uang ganti rugi kepada pekerja/buruh perempuan harian lepas tersebut sebesar upah pekerja/buruh sampai batas waktu berakhirnya jangka waktu perjanjian kerja.

Pekerja/buruh perempuan yang memperoleh pemberian cuti haid yang diatur di dalam perjanjian kerja, peraturan perusahaan, atau perjanjian kerja bersama, akan tetapi mendapatkan pemutusan hubungan kerja oleh perusahaan karena alasan cuti haid yang disertai rasa sakit saat masa haidnya, terhadap hal tersebut dapat dilakukan upaya hukum non litigasi maupun upaya hukum litigasi. sebagai pekerja/buruh harian lepas yang mengikuti PKWT jika hak normatif pekerja/buruh tersebut dilanggar seperti halnya upah, keselamatan dan kesehatan kerja maka pekerja/buruh perempuan harian lepas tersebut dapat melakukan upaya-upaya yang telah dijelaskan oleh peraturan perundangundangan layaknya pekerja lain. Mekanisme penyelesaian hubungan kerja sesuai dengan Undang-Undang Nomor 2 Tahun 2004, yaitu para pihak terlebih dahulu melakukan penyelesaian perselisihan melalui perundingan bipartit antara kedua belah pihak untuk mencapai kesepakatan. Apabila penyelesaian dengan cara bipartit gagal, para pihak dapat menyelesaikan perselisihan dengan upaya tripartit seperti mediasi, konsiliasi, atau arbitrase dan apabila upaya tersebut telah dilakukan tetapi belum mencapai kesepakatan, pihak yang merasa dirugikan dapat mengajukan gugatan kepada Pengadilan Hubungan Industrial pada Pengadilan Negeri tempat pekerja/buruh tersebut bekerja.

\section{Daftar Bacaan}

\section{Buku}

Andi Fariana, Aspek Legal Sumber Daya Manusia Menurut Hukum Ketenagakerjaan (Mitra Wacana Media 2012).

Hardijan Rusli, Hukum Ketenagakerjaan (Ghalia Indonesia 2004). 
Ferdy Dwiyanda: Pemutusan Hubungan Kerja...

Lalu Husni, Penyelesaian Hubungan Industrial Melalui Pengadilan \& Di Luar Pengadilan (Raja grafindo Persada 2004).

Lanny Ramli, Hukum Ketenagakerjaan (Airlangga University Press 2008).

Peter Mahmud Marzuki, Penelitian Hukum (Kencana 2008).

Sudiarto \& Zaeni Asyhadie, Mengenal Abitrase Salah Satu Alternatif Penyelesaian Sengketa Bisnis (Raja Grafindo Persada 2004).

Zaeni Asyhadie, Hukum Kerja: Hukum Ketenagakerjaan Bidang Hubungan Kerja (Rajawali Pers 2013).

\section{Jurnal}

Ni Wayan Mega Jayantri, 'Perlindungan Hukum Terhadap Pekerja Perempuan Pada Malam Hari Di Minimarket Alfamart Mataram (Studi Berdasarkan Undang-Undang No. 13 Tahun 2003 Tentang Ketenagakerjaan)' (2013) 1 Jurnal Ilmiah.

Sali Susiana, 'Perlindungan Hak Pekerja Perempuan Dalam Perspektif Feminisme' [2017] Pusat Penelitian Badan Keahlian DPR RI.

Ujang Charda S, 'Model Penyelesaian Perselisihan Hubungan Industrial Dalam Hukum Ketenagakerjaan Setelah Lahirnya Undang-Undang Nomor 2 Tahun 2004' (2017) 1 Jurnal Wawasan Yuridika Fakultas Hukum Universitas Subang.

\section{Skripsi}

Arum Setiyoningsih, Perlindungan Hukum Pada Pekerja/Buruh Harian Lepas Dalam Pemberian Jaminan Sosial Di Perusahaan (Fakultas Hukum Universitas Airlangga 2018).

Fisa van Iman, Perlindungan Hukum Terhadap Tenaga Kerja Harian Lepas Dengan Badan Penyelenggara Jaminan Sosial (BPJS Ketenagakerjaan) (Fakultas Hukum Universitas Airlangga 2015).

\section{Laman}

Thareq Akmal Hibatullah, 'Sanksi Di UU Ketenagakerjaan Yang Wajib Diketahui Oleh Pengusaha' (Smart Legal Indonesia, 2019) <https://smartlegal.id/ smarticle/2019/02/27/sanksi-uu-ketenagakerjaan/>. 